\title{
Prognostic factors after pneumonectomy in non-small cell lung cancer
}

\author{
Cemal Aker $^{1}$ iD, Celal Buğra Sezen ${ }^{1}$ id, Mustafa Vedat Dogru' ${ }^{1}$, Ali Murat Akç11 ${ }^{1}$, \\ Umut Kilimci $^{1}$ (D), Semih Erduhan ${ }^{1}$ (D) Levent Cansever $^{1}$ (D) $\operatorname{Muzaffer~Metin}^{1}$ (D),
}

1 Health Sciences University Yedikule Chest Diseases and Thoracic Surgery Training and Research Hospital, Department of Thoracic Surgery, Istanbul, Turkey

\begin{abstract}
Background: This study aims to evaluate the factors affecting survival and mortality in patients who underwent pneumonectomy for non-small cell lung cancer.

Methods: The study included 241 pneumonectomy patients. Demographic data, mortality, histopathological characteristics, tumor stages, and 5-year survival rates were analyzed.

Results: The study included nine women (3.7\%) and 232 men (96.3\%). The patients' mean age was 58.4 \pm 8.0 (34-81) years. Fortyfive patients $(18.7 \%)$ were 65 years of age or older, and 196 patients $(81.3 \%)$ were less than 65 years of age. The 30 -day postoperative mortality rate was $7.9 \%(n=19)$. The only factor affecting mortality was determined as age 65 and over $(p=0.012)$. The median survival time was 52 months, and the 5-year survival rate was $49.4 \%$. In multivariate analysis, advanced age, pN2 status, not receiving neoadjuvant treatment, performing sampling lymph node dissection, and not receiving adjuvant treatment were poor prognostic factors.

Conclusion: Age, pN2 status, neoadjuvant and adjuvant therapy, and lymph node dissection technique were determined as the most important prognostic factors affecting survival in patients who underwent pneumonectomy for non-small cell lung cancer. Age was the most important factor affecting mortality.
\end{abstract}

Keywords: Prognosis, Pneumonectomy, Survival Rate, Carcinoma, Non-Small-Cell Lung. 


\section{INTRODUCTION}

Lung carcinomas are currently the leading cause of cancerrelated deaths. In non-small cell lung carcinoma, surgical treatment in the early stage is the gold standard. Although lobectomy is the most common resection performed for lung cancer, extended lung resections are required in some cases due to invasion of surrounding tissues.

Despite advances in surgical techniques, pneumonectomy still has higher morbidity and mortality rates than other anatomic resections. As it is associated with higher morbidity and mortality, compared to other lung resections, the effect of pneumonectomy on long-term survival is still controversial (1).

This study aims to evaluate the factors affecting survival and mortality in patients who underwent pneumonectomy for non-small cell lung cancer.

\section{MATERIALS AND METHODS}

This study involved a retrospective analysis of data pertaining to patients who underwent pneumonectomy due to non-small cell lung carcinoma between January 2008 and December 2016. A total of 351 pneumonectomy patients were initially evaluated for the study. Of these, 11 patients whose data could not be accessed, eight patients who underwent incomplete resection, 32 patients who underwent completion pneumonectomy, 51 patients who underwent carinal sleeve pneumonectomy, and eight patients who underwent pneumonectomy due to complication were excluded. Histopathologic results other than squamous cell carcinoma and adenocarcinoma cell type were excluded in order to include homogeneous groups in the study. Consequently, the study included 241 patients. 9 of 29 patients received neoadjuvant treatment for N2 disease, 20 patients received neoadjuvant treatment for tumor size.

This study was approved by the clinical research ethics committee of the Health Sciences University, İstanbul Training and Research Hospital (Date: 28.06.2019 number: 1883).

\section{Preoperative Evaluation}

Preoperative thoracic computed tomography (CT) was ordered for all patients. In addition, positron emission tomography (PET-CT) and cranial magnetic resonance imaging (MRI) were requested for all patients to evaluate for distant metastases. Pulmonary function tests were done to assess pulmonary reserve. Patients with a history of cardiac disease and those 60 years of age and older were evaluated with echocardiography in the cardiology department. Fiberoptic bronchoscopy was performed preoperatively to evaluate endobronchial lesions. The preoperative mediastinal staging was performed in accordance with ESTS and ATS guidelines (2). Seven patients who received neoadjuvant due to $\mathrm{N} 2$ disease were evaluated by invasive staging (mediastinoscopy or EBUS) before resection. Resection was planned for patients who were found $\mathrm{pN} 0$. The preoperative lymph node evaluation algorithm is shown in Figure 1.

Figure 1 . Preoperative lymph node evaluation algorithm

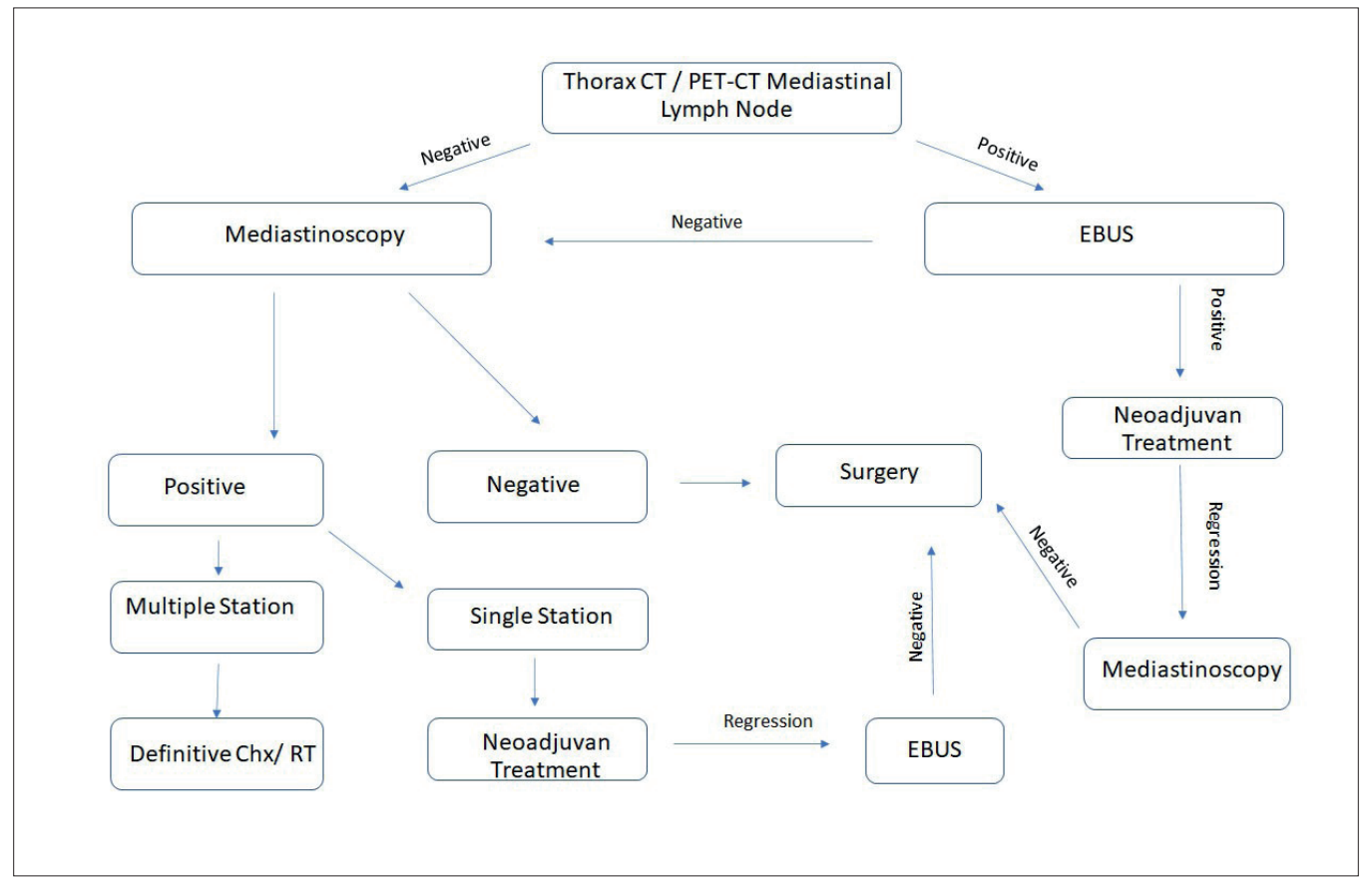


All operations were performed with posterolateral thoracotomy incision. The surgical resections were classified as standard and extended. Extended resections were done in patients with invasion of the pericardium, main pulmonary artery, or chest wall.

In the study, the lymph node dissection technique was divided into sampling and Systematic nodal dissection as defined by ESTS (3).

\section{Postoperative Follow-Up}

Patients were reanimated in the operating room, then monitored in the surgical intensive care unit until their general condition was stable. Intravenous analgesic treatment was used for pain management. The patients' thoracic drains were removed when daily drainage volume was less than $300 \mathrm{ml}$.

The patient's demographic data, length of hospital stay, morbidity and mortality, histopathological characteristics, relapses, and 5-year survival rates were analyzed. In addition, data regarding the patients' age, comorbidities, histopathology results, tumor stage, adjuvant, neoadjuvant therapies received, and survival were obtained from hospital records and the national survival database. Pathologic staging was based on the 8th edition of the TNM classification system. There were 195 patients who received adjuvant therapy during the postoperative period.

Patients were followed with thoracic CT and physical examination in collaboration with oncologists every three months for the first two years, every six months between 2 and 5 years, and once a year after five years.

\section{Statistics:}

The patients' demographic and clinical data were evaluated using descriptive statistics. Chi-square $\left(\chi^{2}\right)$ test or Fisher's Exact test were used to demonstrate relationships between categorical data. Survival was evaluated by KaplanMeier analysis, while log-rank analysis was performed to compare factors. A p-value less than 0.05 was considered statistically significant. All statistical tests were performed using SPSS software (Version 22.0, SPSS Inc., Chicago, IL, USA).

\section{RESULTS}

The study included nine women (3.7\%) and 232 men $(96.3 \%)$. Twenty-nine patients $(12.0 \%)$ received neoadjuvant therapy. The patients' mean age was $58.4 \pm 8.0$ (range $=34-81$ ) years. Forty-five patients $(18.7 \%)$ were 65 years of age or older, and 196 patients $(81.3 \%)$ were less than 65 years of age. Left pneumonectomy was performed on 161 patients $(66.8 \%)$, while right pneumonectomy was performed on 80 patients $(33.2 \%) .62(25.7 \%)$ underwent extended pneumonectomy and 179 patients $(74.3 \%)$ underwent standard pneumonectomy. Fifty-four patients (22.4\%) had adenocarcinoma, 187 (77.6\%) had squamous cell carcinoma. Adjuvant therapy was given to 195 patients $(80.9 \%)$. The demographic characteristics of the patients are shown in Table 1.

Table 1. Comparison of patients' demographic information and histopathological features

\begin{tabular}{|c|c|c|c|}
\hline \multicolumn{2}{|l|}{ Variables } & \multirow{2}{*}{$\begin{array}{l}\text { (n) } \\
232 \\
\end{array}$} & \multirow{2}{*}{$\begin{array}{c}\% \\
96.3 \\
\end{array}$} \\
\hline Gender & Male & & \\
\hline & Female & 9 & 3.7 \\
\hline \multirow[t]{2}{*}{ Age (Year) } & $<65$ & 196 & 81.3 \\
\hline & $>65$ & 45 & 18.7 \\
\hline \multirow[t]{2}{*}{ CCI } & $0-2$ & 137 & 56.8 \\
\hline & $>2$ & 104 & 43.2 \\
\hline \multirow{2}{*}{ Side } & Right & 80 & 33.2 \\
\hline & Left & 161 & 66.8 \\
\hline \multirow[t]{2}{*}{ Resection Type } & Standard & 179 & 74.3 \\
\hline & Extended & 62 & 25.7 \\
\hline \multirow{2}{*}{$\begin{array}{l}\text { Lymph Node } \\
\text { Dissection }\end{array}$} & Sampling & 146 & 60.6 \\
\hline & Systemic & 95 & 39.4 \\
\hline \multirow[t]{2}{*}{ Histopathology } & Adenocarcinoma & 54 & 22.4 \\
\hline & Squamous & 187 & 77.6 \\
\hline \multicolumn{2}{|c|}{ Tumor Diameter $(\mathrm{cm})($ Mean \pm SD) } & \multicolumn{2}{|c|}{$5.24 \pm 2.9$} \\
\hline \multirow{3}{*}{ pN Status } & No & 60 & 24.9 \\
\hline & N1 & 157 & 65.1 \\
\hline & $\mathrm{N} 2$ & 24 & 10 \\
\hline \multirow[t]{4}{*}{ p-Stage } & 0 & 8 & 3.3 \\
\hline & 1 & 14 & 5.8 \\
\hline & 2 & 90 & 37.3 \\
\hline & 3 & 129 & 53.5 \\
\hline \multirow{2}{*}{$\begin{array}{l}\text { Neoadjuvant } \\
\text { Therapy }\end{array}$} & No & 212 & 88 \\
\hline & Yes & 29 & 12 \\
\hline \multirow{2}{*}{$\begin{array}{l}\text { Adjuvant } \\
\text { Therapy }\end{array}$} & No & 46 & 19.1 \\
\hline & Yes & 195 & 80.9 \\
\hline
\end{tabular}

CCI: Charlson Comorbidity Index, SD: Standard Deviation 
The 30-day postoperative mortality rate was $7.9 \%(n=19)$. Gender, Charlson comorbidity index, operation side, histopathology, tumor stage, and neoadjuvant treatment did not affect mortality ( $p>0.05)$. The only factor affecting mortality was determined as age 65 and over $(p=0.012)$. In patients 65 years and older mortality rate was $\% 42.1(n=8)$. Table 2 includes factors affecting mortality.

Table 2. Factors Affecting Mortality

\begin{tabular}{|c|c|c|c|c|c|c|}
\hline \multirow{2}{*}{\multicolumn{2}{|c|}{ Variables }} & \multicolumn{2}{|c|}{ Mortality (-) } & \multicolumn{2}{|c|}{ Mortality (+) } & \multirow[t]{2}{*}{ p-value } \\
\hline & & $(\mathrm{n})$ & $\%$ & $(\mathrm{n})$ & $\%$ & \\
\hline \multirow[t]{2}{*}{ Gender } & Male & 215 & 96.8 & 17 & 89.5 & \multirow[t]{2}{*}{0.104} \\
\hline & Female & 7 & 3.2 & 2 & 10.5 & \\
\hline \multirow[t]{2}{*}{ Age (Year) } & $<65$ & 185 & 83.3 & 11 & 57.9 & \multirow[t]{2}{*}{0.012} \\
\hline & $\geq 65$ & 37 & 16.7 & 8 & 42.1 & \\
\hline \multirow[t]{2}{*}{ CCI } & $0-2$ & 128 & 58.1 & 8 & 42.1 & 0.176 \\
\hline & $>2$ & 93 & 41.9 & 11 & 57.9 & 0.176 \\
\hline \multirow[t]{2}{*}{ Side } & Right & 77 & 34.7 & 3 & 15.8 & \multirow[t]{2}{*}{0.093} \\
\hline & Left & 145 & 65.3 & 16 & 84.2 & \\
\hline \multirow{2}{*}{ Resection Type } & Standard & 164 & 73.9 & 15 & 78.6 & \multirow[t]{2}{*}{0.788} \\
\hline & Extended & 58 & 26.1 & 4 & 21.1 & \\
\hline \multirow[t]{2}{*}{ Histopathology } & Adenocarcinoma & 49 & 22.1 & 5 & 26.3 & \multirow[t]{2}{*}{0.774} \\
\hline & Squamous & 173 & 77.9 & 14 & 73.7 & \\
\hline \multicolumn{2}{|c|}{ Tumor Diameter (cm) (Median) } & \multicolumn{2}{|c|}{5} & \multicolumn{2}{|c|}{5} & 0.641 \\
\hline \multirow[t]{2}{*}{ Tumor Diameter } & $<7 \mathrm{~cm}$ & 203 & 91.4 & 17 & 89.5 & \multirow[t]{2}{*}{0.675} \\
\hline & $\geq 7 \mathrm{~cm}$ & 19 & 8.6 & 2 & 10.5 & \\
\hline \multirow{2}{*}{$\begin{array}{l}\text { Neoadjuvant } \\
\text { Therapy }\end{array}$} & No & 194 & 87.4 & 18 & 94.7 & \multirow[t]{2}{*}{0.484} \\
\hline & Yes & 28 & 12.6 & 1 & 5.3 & \\
\hline
\end{tabular}

CCI: Charlson Comorbidity Index, SD: Standard Deviation, Bold values indicate statistical significance $(\mathrm{p}<0.05)$

The mean follow-up time was 53 months. The median survival time was 52 months, and the 5-year survival rate was $49.4 \%$. In patients 65 years and older, the median survival was 28 months $(31.1 \%)(\mathrm{p}=0.002)$. The 5 -year survival rate was $50.7 \%$ in patients with pN0-N1, while the survival rate was $37.5 \%$ in patients with $\mathrm{pN} 2$ $(p=0.027)$. In patients who received neoadjuvant therapy, the average rate of 5 -year survival was $65.5 \%$, while the survival rate was $47.2 \%$ in patients who did not receive neoadjuvant treatment. $(\mathrm{p}=0.020)$. The mean 5-year survival rate was $62.1 \%$ in pneumonectomy patients who underwent systematic lymph node dissection, while the 5 -year survival rate was $41.1 \%$ in patients who underwent sampling. The 5-year survival rate was $53.6 \%$ in patients who received adjuvant therapy, while the 5-year survival rate was $30.4 \%$ in patients who did not receive adjuvant therapy (Table 3 ). 
Table 3. Factors Affecting Survival in Patients Undergoing Pneumonectomy

\begin{tabular}{|c|c|c|c|c|c|}
\hline \multirow{2}{*}{\multicolumn{2}{|c|}{ Variables }} & \multirow{3}{*}{$\begin{array}{c}5 \text { Year Survival } \\
(\%) \\
53.6\end{array}$} & \multirow{3}{*}{$\begin{array}{c}\text { Median Survival } \\
\text { (Months) } \\
69\end{array}$} & \multirow{3}{*}{$\begin{array}{c}\% 95(\mathrm{CI}) \\
\\
47-90\end{array}$} & \multirow{3}{*}{$\begin{array}{c}\begin{array}{c}\text { Univariate } \\
\text { Analysis }\end{array} \\
\text { p-Value } \\
0.002\end{array}$} \\
\hline & & & & & \\
\hline \multirow[t]{2}{*}{ Age (Year) } & $<65$ & & & & \\
\hline & $>65$ & 31.1 & 28 & $9-46$ & \\
\hline \multirow[t]{2}{*}{ Gender } & Male & 48.3 & 47 & $26-67$ & \multirow[t]{2}{*}{0.310} \\
\hline & Female & 77.8 & 132 & $37-226$ & \\
\hline \multirow[t]{2}{*}{ Side } & Right & 51.3 & 61 & $39-82$ & \multirow[t]{2}{*}{0.520} \\
\hline & Left & 48.4 & 41 & $17-64$ & \\
\hline \multirow[t]{2}{*}{ Histopathology } & Squamous & 51.3 & 65 & $45-84$ & \multirow[t]{2}{*}{0.456} \\
\hline & Adenocarcinoma & 42.6 & 33 & $7-58$ & \\
\hline \multirow[t]{2}{*}{ N Status } & pN0- pN1 & 50.7 & 61 & $41-80$ & \multirow[t]{2}{*}{0.027} \\
\hline & $\mathrm{pN} 2$ & 37.5 & 19 & $0-43$ & \\
\hline \multirow[t]{2}{*}{ Tumor Diameter } & $<7 \mathrm{~cm}$ & 47.6 & 52 & $32-71$ & \multirow[t]{2}{*}{0.853} \\
\hline & $>7 \mathrm{~cm}$ & 49.5 & 33 & $0-115$ & \\
\hline \multirow[t]{2}{*}{ Resection Type } & Standard & 66.5 & 65 & $41-88$ & \multirow[t]{2}{*}{0.229} \\
\hline & Extended & 45.2 & 38 & $9-66$ & \\
\hline \multirow[t]{2}{*}{ Neoadjuvant Therapy } & No & 47.2 & 41 & $22-59$ & \multirow[t]{2}{*}{0.020} \\
\hline & Yes & 65.5 & 96 & $80-126$ & \\
\hline \multirow{2}{*}{$\begin{array}{l}\text { Lymph Node } \\
\text { Dissection }\end{array}$} & Sampling & 41.1 & 35 & $25-44$ & \multirow[t]{2}{*}{0.005} \\
\hline & Systemic & 62.1 & 92 & $58-125$ & \\
\hline \multirow[t]{2}{*}{ Adjuvant Therapy } & No & 30.4 & 13 & $0-26$ & \multirow[t]{2}{*}{0.001} \\
\hline & Yes & 53.8 & 69 & $49-88$ & \\
\hline
\end{tabular}

CCI: Charlson Comorbidity Index. Bold values indicate statistical significance ( $<<0.05)$, CI: Confidential Interval

In multivariate analysis, advanced age, pN2 status, not receiving neoadjuvant treatment, performing sampling lymph node dissection, and not receiving adjuvant treatment were poor prognostic factors. In Table 4, a multivariate analysis of factors affecting survival is included.

Table 4. Multivariate analysis of factor affecting survival

\begin{tabular}{|l|l|c|c|c|}
\hline \multirow{2}{*}{ Variables } & \multirow{2}{*}{ HR } & \multicolumn{2}{|c}{$\%$ CI } & \multirow{2}{*}{ p-Value } \\
\cline { 3 - 5 } & & Lower & Upper & \\
\hline Age & 0.59 & 0.39 & 0.88 & 0.010 \\
\hline N Status & 2.09 & 1.26 & 3.45 & 0.004 \\
\hline Neoadjuvant Therapy & 0.48 & 0.27 & 0.86 & 0.014 \\
\hline Lymph Node Dissection & 0.643 & 0.45 & 0.90 & 0.012 \\
\hline Adjuvant Therapy & 0.48 & 0.32 & 0.72 & $<0.001$ \\
\hline
\end{tabular}

HR: Hazard Ratio, CI: Confidential Interval, Bold values indicate statistical significance $(\mathrm{p}<0.05)$ 


\section{DISCUSSION}

Shapiro et al. stated ages 65 years and older, gender, comorbidities, and steroid use were predictors of mortality (4). In our study, the overall 30-day postoperative mortality rate was $7.9 \%$. In our study, the only factor affecting mortality rate was determined as age. Pneumonectomy is considered a technique that surgeons avoid due to its high risk of perioperative complications and higher morbidity and mortality rates compared to limited anatomic resections. Pneumonectomy is still practiced today when complete surgical resection is required. Many studies have reported higher mortality rates in pneumonectomy than in limited resections (4-8). However, there is still no clear consensus on the perioperative approach for these patients. The prevailing view is to perform either sleeve resections or complex resections that cause less parenchymal loss than pneumonectomy to avoid high mortality rates.

In our study, the most important factors affecting survival were age, N2 disease, and receiving neoadjuvant and adjuvant therapy. In patients 65 years of age and older, the mean survival time was 28 months, while the 5-year survival rate was $31.1 \%$. For patients under 65 years of age, these values were 69 months and $53.6 \%$, respectively $(\mathrm{p}<0.001)$. Cusumano et al. reported that N2 status was a factor associated with poor prognosis (9). In our study, the mean survival times among patients with and without N2 lymph node involvement were 19 months and 61 months, respectively $(p=0.027)$. Consistent with the literature, nodal involvement was one of the factors associated with poor prognosis (10). This emphasizes the importance of preoperative mediastinal staging in patients planned for pneumonectomy. In a 2010 report of a randomized phase 3 trial, Pisters et al. reported that neoadjuvant therapy increased survival rates but that the difference did not reach statistical significance (11). In the same study, it was also reported that adjuvant chemotherapy provided a significant survival benefit. In our study, adjuvant therapy was found to be the factor that provided a significant survival benefit. Patients who received adjuvant therapy survived for a mean of 69 months, compared to 13 months for those who did not $(\mathrm{p}=0.001)$. The 5 -year survival rate of patients who received adjuvant therapy was 53.8\%, significantly higher than the 5-year survival rate of those who did not $(30.4 \%)$. Similar studies also reported that adjuvant therapy administered after complete resection significantly increased survival rates (12).
There are many studies on the role of neoadjuvant therapy in resectable lung cancer, but there is still controversy regarding its survival benefit (13). Some randomized trials and meta-analyses indicate that neoadjuvant therapy improves survival (14). However, other studies have suggested that it does not confer any survival benefit and in some single- and multicenter prospective randomized studies, performing pneumonectomy after neoadjuvant therapy was reported to have an adverse effect on mortality and morbidity (15-17).

Systematic lymph node dissection is the standard procedure in resection for lung cancer, but the value of this approach for survival and nodal staging is still uncertain. Adachi et al. found no significant differences between nodal sampling groups and systematic dissection patients' overall survival (18). Handa et al., in their study about segmentectomy patients, stated that performing mediastinal lymph node dissection was found to provide more appropriate pathological staging by harvesting more lymph nodes and the mediastinal lymph node dissection group tended to have a better prognosis (19). In this study, performing systemic lymph node dissection group has a better prognosis than the sampling group.

Potential sources of bias in the present study include its retrospective design, the inclusion of operations performed by different surgeons, and the small number of women in the patient sample. Moreover, the patients' lack of disease-free survival data is a source of bias in the results of the geriatric patient group.

In conclusion, age, pN2 status, neoadjuvant and adjuvant therapy, and lymph node dissection technique were determined as the most important prognostic factors affecting survival in patients who underwent pneumonectomy for non-small cell lung cancer. Age was the most important factor affecting mortality. Further investigation is needed to clarify the value of prognostic factors.

\section{Declarations}

The authors received no financial support for the research and/or authorship of this article. There is no conflict of interest.

This study was approved by the clinical research ethics committee of the Health Sciences University, İstanbul Training and Research Hospital (Date: 28.06.2019 number: 1883). 


\section{REFERENCES}

1. Yazgan S, Gursoy S, Ucvet A, Samancilar O, Erbaycu AE, Unal M, et al. Pneumonectomy; a risky type of resection in non-small cell lung cancer: survival and mortality analysis. Curr Thorac Surg. 2018;3(3).

2. Rusch VW, Asamura H, Watanabe H, Giroux DJ, Rami-Porta R, Goldstraw P. The IASLC lung cancer staging project: a proposal for a new international lymph node map in the forthcoming seventh edition of the TNM classification for lung cancer. J Thorac Oncol. 2009;4(5):568-77.

3. De Leyn P, Dooms C, Kuzdzal J, Lardinois D, Passlick B, Rami-Porta $\mathrm{R}$, et al. Revised ESTS guidelines for preoperative mediastinal lymph node staging for non-small-cell lung cancer. Eur J Cardiothorac Surg. 2014;45(5):787-98.

4. Shapiro M, Swanson SJ, Wright CD, Chin C, Sheng S, Wisnivesky J, et al. Predictors of major morbidity and mortality after pneumonectomy utilizing the Society for Thoracic Surgeons General Thoracic Surgery Database. Ann Thorac Surg. 2010;90(3):927-35.

5. Schneider L, Farrokhyar F, Schieman C, Shargall Y, D'Souza J, Camposilvan I, et al. Pneumonectomy: the burden of death after discharge and predictors of surgical mortality. Ann Thorac Surg. 2014;98(6):1976-82.

6. Kalathiya RJ, Saha SP. Pneumonectomy for non-small cell lung cancer: outcomes analysis. South Med J. 2012;105(7):350-4.

7. Pekçolaklar A, Nalbant M, Metin M. The factors affecting morbidity, mortality and survival in patients who underwent intrapericardial resections due to non-small cell lung cancer. Curr Thorac Surg. 6(1).

8. Lee M, Razi SS. Pulmonary Sleeve Resection. StatPearls [Internet]. 2020;

9. Cusumano G, Marra A, Lococo F, Margaritora S, Siciliani A, Maurizi G, et al. Is sleeve lobectomy comparable in terms of short- and long-term results with pneumonectomy after induction therapy? A multicenter analysis. Ann Thorac Surg. 2014;98(3):975-83.

10. Parissis H, Leotsinidis M, Hughes A, McGovern E, Luke D, Young V. Comparative analysis and outcomes of sleeve resection versus pneumonectomy. Asian Cardiovasc Thorac Ann. 2009;17(2):175-82.

11. Pisters KMW, Vallières E, Crowley JJ, Franklin WA, Bunn PA, Ginsberg RJ, et al. Surgery with or without preoperative paclitaxel and carboplatin in early-stage non - small-cell lung cancer: Southwest oncology group trial S9900, an intergroup, randomized, phase III trial. J Clin Oncol. 2010;28(11):1843-9.

12. Douillard J-Y, Rosell R, De Lena M, Carpagnano F, Ramlau R, Gonzáles-Larriba JL, et al. Adjuvant vinorelbine plus cisplatin versus observation in patients with completely resected stage IB-IIIA nonsmall-cell lung cancer (Adjuvant Navelbine International Trialist Association [ANITA]): a randomised controlled trial. Lancet Oncol. 2006;7(9):719-27.

13. Kim AW, Boffa DJ, Wang Z, Detterbeck FC. An analysis, systematic review, and meta-analysis of the perioperative mortality after neoadjuvant therapy and pneumonectomy for non-small cell lung cancer. j Thorac Cardiovasc Surg. 2012;

14. Berghmans T, Paesmans M, Meert AP, Mascaux C, Lothaire P, Lafitte $\mathrm{JJ}$, et al. Survival improvement in resectable non-small cell lung cancer with (neo)adjuvant chemotherapy: Results of a meta-analysis of the literature. Lung Cancer. 2005 Jul 1;49(1):13-23.

15. Martin J, Ginsberg RJ, Abolhoda A, Bains MS, Downey RJ, Korst RJ, et al. Morbidity and mortality after neoadjuvant therapy for lung cancer: the risks of right pneumonectomy. Ann Thorac Surg. 2001 Oct 1;72(4):1149-54.
16. Doddoli C, Barlesi F, Trousse D, Robitail S, Yena S, Astoul P, et al. One hundred consecutive pneumonectomies after induction therapy for non-small cell lung cancer: An uncertain balance between risks and benefits. j Thorac Cardiovasc Surg. 2005;

17. Mattson K V, Abratt RP, Ten Velde G, Krofta K. Docetaxel as neoadjuvant therapy for radically treatable stage III non-small-cell lung cancer: a multinational randomised phase III study. Ann Oncol. 2003;14(1):116-22.

18. Adachi H, Sakamaki K, Nishii T, Yamamoto T, Nagashima T, Ishikawa $\mathrm{Y}$, et al. Lobe-specific lymph node dissection as a standard procedure in surgery for non-small cell lung cancer: a propensity score matching study. J Thorac Oncol. 2017;12(1):85-93.

19. Handa $Y$, Tsutani $Y$, Mimae T, Miyata $Y$, Ito H, Nakayama H, et al. Appropriate Extent of Lymphadenectomy in Segmentectomy: A Multicenter Study. Jpn J Clin Oncol. 2021;51(3):451-8. 